\title{
RELATIONSHIPS BETWEEN LEVELS OF MOTOR COORDINATION, ATTENTION AND PHYSICAL ACTIVITY IN CHILDREN: THE MEDIATION MODEL
}

\author{
Jakub Kokštejn, Rudolf Psotta*, Pavel Frýbort
}

Faculty of Physical Education and Sport, Charles University, Prague, Czech Republic

*Faculty of Physical Culture, Palacký University, Olomouc, Czech Republic

Submitted in November, 2012

BACKGROUND: Current findings suggest that physical activity of children with developmental difficulties may be limited by low level of motor coordination. Motor difficulties are often connected with children suffering from attention deficit disorder.

OBJECTIVE: The aim of the study was to find out the level of physical activity (PA) in older school-age children with motor difficulties (MD) in comparison with children without MD and to reveal possible mediate impact on attention between the level of motor skills and PA in children of this age.

METHODS: Participants were divided into two groups - 15 children with MD (age $13.7 \pm 1.6$ years) and 27 children without MD (age 13.3 \pm 1.4 years). Motor functions were assessed by means of test battery MABC-2, weekly physical activity by means of Actigraph accelerometer and attention by both $\mathrm{d} 2$ and numeric square tests. To estimate the mediation of the attention level we have used Baron's and Kenny's (1986) analysis.

RESULTS: In most of the indicators of PA, children with MD reached lower value than those without MD. The differences of statistical significance were found in the number of steps per week and weekdays $(d=0.50$ and 0.64 respectively) and in PA of a very high intensity $(d=2.00)$ in boys with and without MD. In girls with MD we have found out significantly less time spent in vigorous intensity PA $(d=0.86)$. The study results support the hypothesis of developmental motor deficits to be a risk factor for PA in older school-age children. Significant mediation effect of concentration of attention in the relationship between the level of motor skills and PA was observed in three cases - in the relationship between gross motor skills on the one hand, and energy expenditure per week and weekdays, and vigorous intensity PA per week on the other. The amount of mediation effect of attention concentration ranged between $12-22 \%$.

CONCLUSION: The study has indicated that children's participation in PA can be strongly influenced by the level of their interceptive and targeting skills, in which visuomotor coordination lies, and that reduced the child's ability to concentrate may be one of the mediate factors causing lower PA.

Keywords: Visuomotor coordination, balance, energy expenditure, steps, concentration, mediation.

\section{INTRODUCTION}

One of the key factors that may affect children's participation in physical activity (PA) is the level of their motor skills. Especially children with developmental coordination disorder (DCD) were assumed to have reduced participation in movement activities (Baerg, Cairney, Hay, Rempel, Mahlberg, \& Faught, 2011; Hands \& Larkin, 2006; Cairney, Hay, Faught, Wade, Courna, \& Flouris, 2005).

The essence of DCD is a delayed motor coordination development while a child possesses normal intellect and does not have other neurological disorders. DCD manifests in difficulties in the execution of activities of daily life and specific movement skills such as sport and games (APA, 2000). Delayed or immature motor development affects fine and gross motor coordination and balance (Chambers \& Sugden, 2006; Barnhart, Davenport, Epps, \& Nordquist, 2003; APA, 2000). Typical symptoms of DCD are problems in the body scheme, spatial perception and body position (Wann, Williams, \& Rushton, 1998), sensory integration (Wilms Floet \& Maldonado-Durán, 2006; Cermak \& Larkin, 2002), visuomanual and bimanual coordination (Volman \& Geuze, 1998), and visual memory (Dwyer \& McKenzie, 1994).

Some studies supported the hypothesis that children with the motor difficulties or delayed motor development are less physically active (Silman, Cairney, Hay, Klentrou, \& Faught, 2011; Baerg et al., 2011; Castelli \& Valley, 2007; Cantell, Crawford, \& Doyle-Barker, 2008). A potential negative health affect of motor difficulties on PA can be seen in a lower level of cardiorespiratory fitness, anaerobic performance and muscle strength in 
children with DCD compared to children with a normal level of motor skills (Cantell et al., 2008; Cairney, Hay, Faught, Flouris, \& Klentrou, 2007; Hands \& Larkin, 2006).

Successful academic achievement of a child in a school including his/her movement skill performance is strongly dependent on the level of his/her attention as the relatively stable psychic ability. It is assumed that the essence of the influence of attention on execution of motor skills lies in the fact that attention determines the quality of selection and processing of sensory stimuli, which are important for planning and control of intentional movements (Maylor, 2001; Sundermier, Woollacott, Roncesvalles, \& Jensen, 2001). The level of attention as the mechanism which dynamizes perceptual and cognitive processes can influence a quality of the integration of stimuli of the different modes, their subsequent processing, movement response selection and programming of a response.

The prevalence of a lower level of motor skills in children is very often associated with attention deficit disorder (ADD) or attention deficit hyperactivity disorder (ADHD) (Chen, Tseng, Hu, \& Cermak, 2009; Licari \& Larkin, 2008; Dewey, Kaplan, Crawford, \& Wilson, 2002). Martin, Piek, and Hay (2006), Dewey et al. (2002) reported $50 \%$ of children with motor difficulties have concurrently been diagnosed with ADHD.

In the school-age children with ADHD and the combination of DCD and ADHD, the significantly lower static balance was found as compared to the children without these disorders (Shum \& Pang, 2009; Licari \& Larkin, 2008). These findings support Posner's hypothesis mentioned by Woollacott and ShumwayCook (2002). This hypothesis considers attention as a mechanism that determines the quality of information selection and processing being relevant for balance control and, more generally, for control in execution of many types of movements. Some studies suggested that attention significantly contributes to postural stabilization of an individual, although it is traditionally considered to be an automatically controlled function (Beauchet, Dubost, Gonthier, \& Kressig, 2005; Woollacott \& Shumway-Cook, 2002; Rankin, Woollacott, Shumway-Cook, \& Brown, 2000). In children is more likely suggested a higher contribution of the cognitive resources for controlling the balance and simple movements in comparison with pubescent children (Woollacott \& Shumway-Cook, 2002). Thus, we can suggest attention to have important role for perception, planning and motor control.

Based on the afore mentioned role of attention for information processing and motor control, and the relatively frequent occurrence of attention deficit in children with developmental motor difficulties, it can be assumed that the impact of low level of motor co- ordination on lower daily PA may be partly mediated by a child's level of attention. Therefore the aim of the study was, in the first step, to determine whether there are differences in PA of children with and without motor difficulties, and in the second step to reveal to what extent can the relationship between a level of motor coordination of children and their PA be mediated by the level of their attention.

\section{METHODS}

\section{Research design}

The study focused on an investigation of the relationship between motor difficulties (MD) and physical activity (PA) in older school-age children. At the same time, the study examined whether this relationship may be mediated by an individual's level of attention. According to these relationships, we expected the level of motor coordination to be the independent variable, PA to be the dependent variable, and the level of attention to be the mediation variable that mediates the relationship between the level of motor coordination and PA.

\section{Participants}

The sample of 212 children aged $12.7 \pm 1.0$ years from six public primary schools located in four regions of the Czech Republic underwent a motor coordination development assessment using the Movement Assessment Battery for Children-2 (MABC-2; Henderson, Sugden, \& Barnett, 2007) (see the section Motor skill assessment). The children who were identified as the subjects with moderate or significant motor difficulties $(n=15$, age $13.7 \pm 1.6$ years, 8 girls and 7 boys at the age $14.1 \pm 1.2$ years and $13.3 \pm 2.0$ years respectively) ( $\mathrm{MD}^{+}$children) were included into the study. In addition, the group of children without motor difficulties ( $\mathrm{MD}^{-}$children) was formed from random selection of the children identified as those without motor difficulties and concurrently who were schoolmates attending the same classes as the $\mathrm{MD}^{+}$children ( $n=27$, age $13.3 \pm 1.4$ years; 16 girls and 11 boys aged $13.6 \pm 1.5$ years and $13.5 \pm 1.6$ years, respectively). This study had been approved by the Scientific Panel for Psychology and Education of the Czech Science Foundation. The study was conducted in accordance with the Declaration of Helsinki. The testing of children was carried out after receiving informed written consent from school principals and the parents of the children.

\section{Motor skill assessment}

The motor skill assessment and identification of motor difficulties in the children was carried out with the MABC-2 (Henderson et al., 2007). The condi- 
tions, procedure and administration of the MABC-2 tests were kept according to the Examiner's Manual (Henderson et al., 2007). This test battery includes following tests:

1. turning pegs (MD1) (in the units s), triangle with nuts and bolts (MD 2) (s), and drawing trail (MD 3) (a number of errors) for assessment of manual dexterity (fine motor coordination);

2. catching with one hand (AC 1) and throwing at wall target (AC 2) (a number of successful attempts) for assessment of gross motor coordination;

3. two-board balance (Bal. 1) (s), walking toe-to-heel backwards (Bal. 2) (a number of successful steps), and zig-zag hopping (Bal. 3) (a number of successful jumps) for assessment of balance.

According to the MABC-2 Manual (Henderson et al., 2007) the raw score achieved in each test was converted to the standard score (SS) according to the ageadjusted norms on the 19 point scale with mean \pm SD $10 \pm 3$. The level of three motor components - fine and gross motor coordination, and balance were determined by the sum of SS in the relevant tests converted to the component SS and percentile equivalent. The overall level of motor coordination development of a given child was expressed as a sum of SS of all eight tests (total test score; TTS), which was converted to SS and percentile equivalent. Henderson et al. (2007) and Chow et al. (2002) showed the good construct validity of MABC-2. Reliability of the MABC-2 tests for the age band of 11-16 years was reported with $r=0.80$ and objectivity $r=0.95-1.00$ for TTS (Henderson et al., 2007).

The motor skill assessment of children was conducted by a team of the trained research assistants. In accordance with the Examiner's manual (Henderson et al., 2007), two categories of the $\mathrm{MD}^{+}$children were identified: the children with TTS at the level of the $15^{\text {th }}-6^{\text {th }}$ percentile $(\mathrm{P})$ showing the moderate motor difficulties, and the children with TTS at the level $\mathrm{P} \leq 5$ which indicates the significant motor difficulties suggesting DCD. The motor development assessment was completed in the schools always during morning hours.

\section{Weekly physical activity assessment}

Weekly physical activity (PA) in the children was assessed during the June using ActiGraph GT1M accelerometers (ActiGraph, LLC, Inc., Fort Walton Brach, FL, USA).

Monitoring of PA with the accelerometer was supplemented by completing the written PA self-record (Frömel, Novosad, \& Svozil, 1999). The instructions given the children for use of the device and completion of PA self-report during consecutive seven days were the same as described in the study by Frömel, Pelclová, Skalik, Nováková Lokvencová, and Mitáš (2012).

After the instructions children's understanding them and their competency for use of device and PA self-report was verified.

An Actigraph accelerometer was reported as the reliable method with intraclass correlations $>0.80$ and generalizability values $>0.60$ (Welk, Schaben, \& Morrow, 2004). The validity of PA assessment using this device was found with SEM 1.8-8.4\% for walking and running speed up to $9 \mathrm{~km} \times \mathrm{h}^{-1}$ (Psotta, Vodička, Heller, \& Soukup, 2007). The following variables as the indicators of PA were calculated:

1. mean daily active energy expenditure for the all week $\left(\mathrm{AEE}_{\mathrm{w}} ; \mathrm{kcal} \times \mathrm{kg}^{-1} \times \mathrm{day}^{-1}\right)$, and separately at weekdays $\left(\mathrm{AEE}_{\mathrm{wD}} ; \mathrm{kcal} \times \mathrm{kg}^{-1} \times \mathrm{day}^{-1}\right)$ and weekend days $\left(\mathrm{AEE}_{\mathrm{WEND}} ; \mathrm{kcal} \times \mathrm{kg}^{-1} \times \mathrm{day}^{-1}\right)$;

2. daily number of steps at the total week, and separately at weekdays and weekend days (

3. daily time spent in inactivity, light PA (< 3 METs), moderate PA (3-5.9 METs), vigorous PA (6-9 METs) and very high intensity PA (> 9 METs) during the all week $\left(\min \times\right.$ day $\left.^{-1}\right)$. These variables were generated from the analysis of counts data for younger subjects based on the conception by Freedson, Melanson, and Sirard (1998).

\section{Attention assessment}

Attention of children was assessed using two psychodiagnostic methods - the test of attention d2 (d2 test) (Brickenkamp \& Zillmer, 2000) in its Czech version by Balcar (2000), and the Numerical square test by Jirásek (1975).

The $\mathrm{d} 2$ test is a time-limited test of selective attention, which assesses individual level of attention and concentration. The task for a subject is to search visually the target signs - the letter d with two short lines under this letter or above this letter, or with one short line under and one line above this letter, while looking through the fourteen rows of the different variants of the letter $d$ and $p$ as the visual signs. The following attention variables were calculated:

- Total performance (TP) as the difference between the total number of the signs searched by a subject and the total number of errors $\mathrm{E}$, where $\mathrm{E}=$ error of omission + error of confusion. TP expresses the rate of produced attention in relation to its accuracy.

- Concentration performance (CP) as the difference between total number of target signs correctly found and the errors of confusion. CP is an indicator of concentration of attention, and the indirect indicator of the visual differentiation ability of a subject (Brickenkamp \& Zillmer, 2000). Raw scores of both variables were converted to the age-adjusted standard score on a scale from 70 to 130 points 
with an average of 100 points, and also converted to the percentiles.

The Numerical square test (Jirásek, 1975) is used for assessment of the individual level of concentration of attention and the extent of the visual field. In the presented table with irregularly located numbers from 1 to 25 , a subject tries to find the numbers in the order from 1 to 25 in the shortest possible time. Ten trials of this task are performed. The total time needed for completion of the ten trials $\left(\mathrm{T}_{\mathrm{NST}} ; \mathrm{s}\right)$ was calculated and converted to age-adjusted standard score - $1^{\text {st }}-3^{\text {rd }}$ deciles - below-average level, $4^{\text {th }}-7^{\text {th }}$ deciles - normal level, $8^{\text {th }}-10^{\text {th }}$ deciles - aboveaverage level.

\section{Statistical methods}

Besides $\mathrm{M} \pm \mathrm{SD}$, the significance of difference was tested using the Cohen's coefficient of the size effect $d$ using pooled SD (Cohen, 1988). The value $d<.50$ was interpreted as a small effect of a factor, which causes a difference, $d=.50-.80$ as a moderate effect, and $d>.80$ as a large effect (Cohen, 1988). If the finding $d \geq .50$ occurred, the statistical significance of the difference was tested by the Student's unpaired t-test $(p \leq 0.05)$ including the F-test $(p \leq 0.05)$. The difference was considered significant if the practical difference $d \geq .50$ was confirmed to be statistically significant.

\section{The analysis of mediation effect according to the Baron and Kenny's model}

Pearson's correlation coefficient was calculated to analyze the relationship between the motor coordination variables and PA variables for the all sample of children $\left(\mathrm{MD}^{+}\right.$children $+\mathrm{MD}^{-}$children $)$. In the case of significant correlation $(p \leq 0.05)$, the potential mediation effect of the indicators of attention on the level of PA using the procedure by Baron and Kenny (1986) was analyzed. This procedure included the following three steps:

- The $1^{\text {st }}$ step - calculation of regression of the dependent variable $\mathrm{Y}$ (each of the PA variables) on the independent variable $\mathrm{X}$ (each of the motor coordination variables) $-\mathrm{Y}=\mathrm{c} \times \mathrm{X}+\mathrm{i}_{\mathrm{e} 1}$.

- The $2^{\text {nd }}$ step - therefore the seven correlations between $\mathrm{Y}$ and $\mathrm{X}$ were found as the statistically significant $(p \leq 0.05)$ in the $1^{\text {st }}$ step of the analysis, the mediation effect of attention as the mediation variable $\mathrm{M}$ was considered, and the regression of $\mathrm{M}$ on $\mathrm{X}$ was calculated $\left(\mathrm{M}=\mathrm{a} \times \mathrm{X}+\mathrm{i}_{\mathrm{e} 2}\right)$. From the all variables of attention underwent this regression, only $\mathrm{T}_{\mathrm{NST}}$ showed significant correlation to only motor variable - gross motor coordination. Thus, the $\mathrm{T}_{\text {NST }}$ could be consider a mediation variable $\mathrm{M}$.
- The $3^{\text {rd }}$ step - from a theoretical point of view, we did not assume the full mediation effect of attention (as M) on the level of PA (as Y) in the subjects. Therefore, this step was not implemented in accordance with the recommendation by Baron and Kenny (1986).

- The $4^{\text {th }}$ step - the regression of the three variables of PA as the Y (elicited in the $1^{\text {st }}$ and $2^{\text {nd }}$ step) on $\mathrm{T}_{\mathrm{NST}}$ (as M; elicited in the $2^{\text {nd }}$ step) and gross motor coordination variable as $X$ (elicited in the $1^{\text {st }}$ and $2^{\text {nd }}$ step) was calculated: $\mathrm{Y}=\mathrm{c}^{\prime} \times \mathrm{X}+\mathrm{b} \times \mathrm{M}+\mathrm{a}+\mathrm{i}_{\mathrm{e} 4}$.

The difference of the regression coefficients $c-c$ ' from the equations calculated in the $1^{\text {st }}$ and $4^{\text {th }}$ step of the analysis, respectively, was used to assess the size of the reduction on the effect of variable $\mathrm{X}$ (motor coordination variable) on Y (i.e. PA) by direct partial mediation effect of the $M$, i.e. attention represented by $\mathrm{T}_{\mathrm{NST}}$. This difference was verified by the multiple of the regression coefficients $a$ and $b$ involved in the regression equations of the $2^{\text {nd }}$ and $4^{\text {th }}$ step of the analysis, respectively. The size of mediation effect was considered to be valid if $(a \times b)=\left(c-c^{\prime}\right)$ (Baron \& Kenny, 1986). The mediation contribution of the attention variable $\mathrm{T}_{\mathrm{NST}}$ for the explanation of a given PA variable was expressed as the percentage of the total explanation from the ratio of the regression coefficient $c^{\prime} \times c^{-1}$.

For statistical analysis we used Statistica 9 software (StatSoft, Inc., Tulsa, OK, USA).

\section{RESULTS}

\section{Motor coordination}

TABLE 1 confirms significant differences of the motor coordination between $\mathrm{MD}^{-}$and $\mathrm{MD}^{+}$children. These two groups did not differ in the anthropometric characteristics (TABLE 1).

\section{Weekly physical activity}

Both $\mathrm{MD}^{+}$boys and $\mathrm{MD}^{+}$girls showed a lower mean daily active energy expenditure (AEE; $\mathrm{kcal} \times \mathrm{kg}^{-1} \times$ day $\left.^{-1}\right)$ in comparison to the $\mathrm{MD}^{-}$boys and $\mathrm{MD}^{-}$girls, respectively, during the whole week, and also separately for weekdays and weekends. However, these differences were not significant (TABLE 2). Between $\mathrm{MD}^{+}$boys and $\mathrm{MD}^{-}$boys were found moderate or large difference in the number of steps per week and specially during the workdays (steps $\times$ day $^{-1}$ ) and further, in the total time of vigorous intensity PA (PA $)$ (6-9 METs) $\left(\min . \times\right.$ day $\left.^{-1}\right)(d=0.5$ to 0.8$)$. However, these differences were not statistically significant (TABLE 2).

The $\mathrm{MD}^{+}$girls when compared with the $\mathrm{MD}^{-}$girls, reached lower values in all three variables of the number of steps and the total time of vigorous intensity PA 
TABLE 1

The basic anthropometric measures and results of the MABC-2 in children with and without motor difficulties

\begin{tabular}{|c|c|c|c|c|}
\hline & $\mathrm{MD}^{+}$children & MD' children & \multirow{2}{*}{$d$} & \multirow{2}{*}{$\begin{array}{c}\text { t-test } \\
p\end{array}$} \\
\hline & $\mathrm{M} \pm \mathrm{SD}$ & $\mathrm{M} \pm \mathrm{SD}$ & & \\
\hline Age (years) & $13.7 \pm 1.6$ & $13.3 \pm 1.4$ & 0.27 & \\
\hline Body weight $(\mathrm{kg})$ & $53.8 \pm 13.4$ & $49.4 \pm 11.6$ & 0.35 & \\
\hline Body height $(\mathrm{cm})$ & $161.5 \pm 10.9$ & $161.3 \pm 8.4$ & 0.02 & \\
\hline $\mathrm{BMI}\left(\mathrm{kg} \times \mathrm{m}^{2}\right)$ & $19.0 \pm 3.4$ & $18.5 \pm 3.6$ & 0.14 & \\
\hline \multicolumn{5}{|c|}{ MABC-2 } \\
\hline Total test score (SS) & $6.4 \pm 0.7$ & $10.7 \pm 2.0$ & $3.19^{\dagger \dagger}$ & $p<0.01$ \\
\hline Fine coordination (SS) & $8.2 \pm 1.7$ & $10.6 \pm 1.8$ & $1.37^{\dagger \dagger}$ & $p<0.01$ \\
\hline Gross coordination (SS) & $5.3 \pm 1.9$ & $9.1 \pm 3.1$ & $1.52^{\dagger \dagger}$ & $p<0.01$ \\
\hline Balance (SS) & $7.7 \pm 2.1$ & $11.9 \pm 2.4$ & $1.87^{\dagger \dagger}$ & $p<0.01$ \\
\hline
\end{tabular}

Legend:

$\mathrm{MD}^{+}$and $\mathrm{MD}^{-}$children - children with and without motor difficulties, $d$ - Cohen's coefficient of effect size, SS - standard score, $p$ - significance level, $\mathrm{M}$ - mean, SD - standard deviation, ${ }^{\dagger \dagger}$ large practical difference

(6-9 METs) $\left(\min . \times\right.$ day $\left.^{-1}\right)$ but these differences were not significant. The only exception was a large practical difference in the total time of vigorous PA $(d=0.86)$ (TABLE 2).

\section{Attention}

There was not found any significant difference between the $\mathrm{MD}^{+}$and $\mathrm{MD}^{-}$children in the total performance (TP) achieved in the $\mathrm{d} 2$ test. In the same test, the $\mathrm{MD}^{+}$boys achieved lower scores in the concentration performance $(\mathrm{CP})(d=0.56)$ as compared with the $\mathrm{MD}^{-}$boys (TABLE 3 ). The total time needed for completing of ten trials in the Numeric square test $\left(\mathrm{T}_{\mathrm{NST}}\right)$ was not significantly different between $\mathrm{MD}^{+}$ and $\mathrm{MD}^{-}$boys, and between $\mathrm{MD}^{+}$and $\mathrm{MD}^{-}$girls (TABLE 3).

Correlations between the motor coordination variables and PA variables, mediation effect of the attention variables

In the $1^{\text {st }}$ step of mediation analysis, seven statistically significant correlations ( $p \leq 0.05$ ) were found between the motor coordination variables and PA variables (TABLES 4, 5).

However, from the all motor coordination variables only the gross motor coordination (standard score) of the children showed a significant relationship to the indicator of concentration of attention $\mathrm{T}_{\mathrm{NST}}$ (decile) as a potential mediation variable $(p \leq 0.05)$ (TABLE 6 see the $2^{\text {nd }}$ step). Therefore in the $4^{\text {th }}$ step of mediation analysis, the regressions of the following PA variables on the gross motor coordination variable and $\mathrm{T}_{\mathrm{NST}}$ were computed:
1. $\mathrm{AEE}_{\mathrm{w}}\left(\mathrm{kcal} \times \mathrm{kg}^{-1} \times \mathrm{day}^{-1}\right)($ TABLE 6), the difference of the regression coefficients $c-c^{\prime}=0.02$ and $11.7 \%$ of the partial mediation effect of the $\mathrm{T}_{\mathrm{NST}}$ in the relationship between the gross motor coordination variable and $\mathrm{AEE}_{\mathrm{w}}$ was found.

2. $\operatorname{AEE}_{\mathrm{wD}}\left(\mathrm{kcal} \times \mathrm{kg}^{-1} \times \mathrm{day}^{-1}\right)(\mathrm{TABLE} 6)$, the difference $c-c^{\prime}=0.02$ and $11.1 \%$ of the partial mediation effect of $\mathrm{T}_{\mathrm{NST}}$ in the relation between the gross motor coordination variable and $\mathrm{AEE}_{\text {wend }}$ was found.

3. Mean daily vigorous intensity $\mathrm{PA}\left(\mathrm{PA}, \min \times \mathrm{day}^{-1}\right)$ (TABLE 6), the difference $c-c^{\prime}=0.04$ and $22.2 \%$ of the partial mediation effect of $\mathrm{T}_{\mathrm{NST}}$ in relation between the gross motor coordination variable and $\mathrm{PA}_{\mathrm{HI}}$ was found.

Validity of the differences $c-c$ ' was confirmed by the agreement of the product of coefficients $a . b$ in the all three analyses of the mediation effect of the indicator of attention $\mathrm{T}_{\mathrm{NST}}$.

\section{DISCUSSION}

Both the children with motor coordination difficulties $\left(\mathrm{MD}^{+}\right)$and children without motor problems $\left(\mathrm{MD}^{-}\right)$showed their average daily PA close to the lower boundary of the health recommendations for the amount of PA in older children - daily energy expenditure 6-8 kcal $\times \mathrm{kg}^{-1} \times$ day $^{-1}$ for older children (Corbin \& Pangrazi, 1996) (TABLE 3). However, the $\mathrm{MD}^{+}$children achieved the recommended values of PA in the three days of a week while $\mathrm{MD}^{-}$children only in one day of a week. 
TABLE 2

The physical activity variables in the children with and without motor difficulties

\begin{tabular}{|c|c|c|c|c|}
\hline & $\mathrm{MD}^{+}$children & MD- children & \multirow{2}{*}{$d$} & \multirow{2}{*}{$\begin{array}{c}\text { t-test } \\
p\end{array}$} \\
\hline & $\mathrm{M} \pm \mathrm{SD}$ & $\mathrm{M} \pm \mathrm{SD}$ & & \\
\hline \multicolumn{5}{|c|}{ AEE - all week $\left(\mathrm{kcal} \times \mathrm{kg}^{-1} \times\right.$ day $\left.^{-1}\right)$} \\
\hline Boys & $5.9 \pm 1.9$ & $6.1 \pm 1.3$ & 0.13 & \\
\hline Girls & $5.1 \pm 1.1$ & $5.4 \pm 1.9$ & 0.20 & \\
\hline \multicolumn{5}{|c|}{ AEE - weekdays $\left(\mathrm{kcal} \times \mathrm{kg}^{-1} \times \mathrm{day}^{-1}\right)$} \\
\hline Boys & $6.3 \pm 1.6$ & $6.9 \pm 1.4$ & 0.40 & \\
\hline Girls & $5.5 \pm 1.0$ & $5.7 \pm 2.0$ & 0.13 & \\
\hline \multicolumn{5}{|c|}{ AEE - weekend days $\left(\mathrm{kcal} \times \mathrm{kg}^{-1} \times \mathrm{day}^{-1}\right)$} \\
\hline Boys & $5.0 \pm 2.7$ & $4.2 \pm 1.9$ & 0.35 & \\
\hline Girls & $4.1 \pm 2.2$ & $4.9 \pm 1.9$ & 0.39 & \\
\hline \multicolumn{5}{|c|}{ Steps in the week $\left(\right.$ steps $\times$ day $^{-1}$ ) } \\
\hline Boys & $8586 \pm 2719$ & $9768 \pm 2010$ & $0.50^{\dagger}$ & 0.152 \\
\hline Girls & $8855 \pm 2959$ & $9365 \pm 2219$ & 0.20 & \\
\hline \multicolumn{5}{|c|}{ Steps in the weekdays $\left(\right.$ steps $\times$ day $\left.^{-1}\right)$} \\
\hline Boys & $8465 \pm 2882$ & $10287 \pm 2837$ & $0.64^{\dagger}$ & 0.103 \\
\hline Girls & $9751 \pm 2626$ & $9865 \pm 2438$ & 0.05 & \\
\hline \multicolumn{5}{|c|}{ Steps in the weekend (steps $\times$ day $^{-1}$ ) } \\
\hline Boys & $8887 \pm 2755$ & $8470 \pm 2952$ & 0.15 & \\
\hline Girls & $6617 \pm 4770$ & $8116 \pm 2436$ & 0.42 & \\
\hline \multicolumn{5}{|c|}{ Inactivity $\left(\min . \times\right.$ day $\left.^{-1}\right)$} \\
\hline Boys & $495 \pm 114$ & $482 \pm 93$ & 0.12 & \\
\hline Girls & $550 \pm 77$ & $528 \pm 65$ & 0.31 & \\
\hline \multicolumn{5}{|c|}{ Light intensity $(3<$ METs $)\left(\min . \times\right.$ day $\left.^{-1}\right)$} \\
\hline Boys & $283 \pm 98$ & $306 \pm 61$ & 0.28 & \\
\hline Girls & $247 \pm 60$ & $286 \pm 76$ & 0.55 & 0.113 \\
\hline \multicolumn{5}{|c|}{ Moderate intensity $(3-5.9$ METs $)\left(\min . \times\right.$ day $\left.^{-1}\right)$} \\
\hline Boys & $57.4 \pm 30.6$ & $55.1 \pm 15.2$ & 0.10 & \\
\hline Girls & $51.6 \pm 22.9$ & $49.1 \pm 17.4$ & 0.12 & \\
\hline \multicolumn{5}{|c|}{ Vigorous PA (6-9 METs) $\left(\min . \times\right.$ day $\left.^{-1}\right)$} \\
\hline Boys & $1.2 \pm 1.7$ & $1.5 \pm 1.7$ & 0.18 & \\
\hline Girls & $0.5 \pm 0.6$ & $1.4 \pm 1.5$ & $0.86^{\dagger \dagger}$ & 0.062 \\
\hline \multicolumn{5}{|c|}{ Very high intensity PA (> 9 METs) $\left(\right.$ min. $\times$ day $\left.^{-1}\right)$} \\
\hline Boys & $0.0 \pm 0.0$ & $0.1 \pm 0.1$ & $2.00^{\dagger \dagger}$ & 0.134 \\
\hline Girls & $0.1 \pm 0.2$ & $0.2 \pm 0.3$ & 0.40 & \\
\hline \multicolumn{5}{|c|}{ Moderate to very high PA $(>3$ METs $)\left(\min . \times\right.$ day $\left.^{-1}\right)$} \\
\hline Boys & $58.3 \pm 32.3$ & $56.5 \pm 15.5$ & 0.08 & \\
\hline Girls & $52.0 \pm 23.1$ & $50.4 \pm 18.8$ & 0.08 & \\
\hline
\end{tabular}

Legend: $\mathrm{MD}^{+}$and $\mathrm{MD}^{-}$children - children with and without motor difficulties, $\mathrm{M}$ - mean, SD - standard deviation, $d$ - Cohen's coefficient of effect size, $p$ - significance level, AEE - active energy expenditure, PA - physical activity, ${ }^{\dagger}$ medium practical difference, ${ }^{\dagger \dagger}$ large practical difference 
TABLE 3

The results of the attention tests in the children with and without motor difficulties

\begin{tabular}{|c|c|c|c|c|}
\hline & $\mathrm{MD}^{+}$children & MD- children & \multirow{2}{*}{$d$} & \multirow{2}{*}{$\begin{array}{c}\text { t-test } \\
p\end{array}$} \\
\hline & $\mathrm{M} \pm \mathrm{SD}$ & $\mathrm{M} \pm \mathrm{SD}$ & & \\
\hline \multicolumn{5}{|c|}{ d2 test - TP (SS) } \\
\hline Boys & $111.0 \pm 17.0$ & $109.2 \pm 17.6$ & 0.10 & \\
\hline Girls & $114.6 \pm 12.4$ & $113.7 \pm 12.7$ & 0.07 & \\
\hline \multicolumn{5}{|c|}{ d2 test - CP (SS) } \\
\hline Boys & $90.6 \pm 24.9$ & $103.0 \pm 19.6$ & $0.56^{\dagger}$ & 0.127 \\
\hline Girls & $111.1 \pm 13.9$ & $109.5 \pm 15.2$ & 0.11 & \\
\hline \multicolumn{5}{|c|}{ Numerical square test $-\mathrm{T}_{\mathrm{NST}}($ decile $)$} \\
\hline Boys & $2.4 \pm 1.4$ & $3.0 \pm 1.5$ & 0.41 & \\
\hline Girls & $2.4 \pm 1.4$ & $3.0 \pm 1.5$ & 0.41 & \\
\hline
\end{tabular}

Legend: $\mathrm{MD}^{+}$and $\mathrm{MD}^{-}$children - children with and without motor difficulties, $\mathrm{M}$ - mean, $\mathrm{SD}$ - standard deviation, $d$ - Cohen's coefficient of effect size, $p$ - significance level, TP - total performance, CP - concentration performance, $\mathrm{SS}$ - standard score, $\mathrm{T}_{\mathrm{NST}}-$ total time in the Numeric square test, ${ }^{\dagger}$ medium practical difference

\section{TABLE 4}

The correlations between the motor coordination and the physical activity variables in the children $(n=42)$

\begin{tabular}{|l|c|c|c|c|c|c|}
\hline \multirow{2}{*}{$\begin{array}{l}\text { Motor coordination } \\
\text { (SS) }\end{array}$} & \multicolumn{3}{|c|}{$\begin{array}{c}\text { Active energy expenditure } \\
\left(\mathbf{k c a l}^{\times} \mathbf{~ k g}^{-1} \times \mathbf{d a y}^{-1} \text { ) }\right.\end{array}$} & \multicolumn{3}{c|}{$\begin{array}{c}\text { Steps } \\
\text { (steps } \times \text { day }^{-1} \text { ) }\end{array}$} \\
\cline { 2 - 7 } & All week & Weekdays & Weekend days & All week & Weekdays & Weekend days \\
\hline TTS & 0.18 & 0.19 & 0.12 & 0.15 & 0.15 & 0.07 \\
\hline Fine motor coordination & 0.06 & 0.05 & 0.06 & -0.06 & -0.07 & -0.01 \\
\hline Gross motor coordination & $0.35^{*}$ & $0.39^{* *}$ & 0.17 & 0.22 & 0.22 & 0.12 \\
\hline Balance & 0.05 & 0.03 & 0.10 & 0.15 & 0.14 & 0.10 \\
\hline
\end{tabular}

Legend: SS - standard score, TTS - total test score in the MABC-2, ${ }^{* *} p<0.01,{ }^{*} p<0.05$

TABLE 5

The correlations between the motor coordination and the physical activity variables in the children $(n=42)$

\begin{tabular}{|l|c|c|c|c|c|}
\hline \multirow{2}{*}{$\begin{array}{l}\text { Motor coordination } \\
\text { (SS) }\end{array}$} & \multicolumn{5}{|c|}{ The mean daily time spent in the particular intensities of PA } \\
\cline { 2 - 6 } & Inactivity & $\begin{array}{c}\text { Low } \\
(<\mathbf{3} \text { METs })\end{array}$ & $\begin{array}{c}\text { Moderate } \\
(\mathbf{3 - 5 . 9} \text { METs })\end{array}$ & $\begin{array}{c}\text { Vigorous } \\
(\mathbf{6 - 9} \text { METs) }\end{array}$ & $\begin{array}{c}\text { Very high } \\
\text { (> 9 METs) }\end{array}$ \\
\hline TTS & -0.10 & 0.10 & 0.01 & $0.37^{* *}$ & $0.28^{* *}$ \\
\hline Fine motor coordination & -0.01 & 0.05 & -0.18 & 0.16 & 0.03 \\
\hline Gross motor coordination & -0.10 & 0.09 & 0.06 & $0.34^{*}$ & 0.23 \\
\hline Balance & -0.20 & 0.19 & 0.11 & $0.31^{*}$ & $0.29^{*}$ \\
\hline
\end{tabular}

Legend: SS - standard score, TTS - total test score in the MABC-2, ${ }^{* *} p<0.01,{ }^{*} p<0.05$ 


\section{TABLE 6}

Results of the individual steps of mediation analysis with $\mathrm{AEE}_{\mathrm{w}} / \mathrm{AEE}_{\mathrm{wD}} / \mathrm{PA}$, gross motor coordination (GMC) and attention variable $\left(\mathrm{T}_{\mathrm{NST}}\right)$

\begin{tabular}{|l|l|c|c|c|}
\hline Step & \multicolumn{1}{|c|}{ Procedure } & $\boldsymbol{r}$ & $\boldsymbol{p}$ & Regression coefficient \\
\hline $1^{\text {st }}$ & the regression of $\mathrm{AEE}_{\mathrm{W}}$ on GMC & 0.35 & $<0.05$ & $\mathrm{c}=0.17$ \\
\hline $2^{\text {nd }}$ & the regression of $\mathrm{T}_{\mathrm{NST}}$ on GMC & 0.27 & $<0.05$ & $\mathrm{a}=0.11$ \\
\hline $4^{\text {th }}$ & the regression of $\mathrm{AEE}_{\mathrm{W}}$ on $\mathrm{T}_{\mathrm{NST}}$ and GMC & 0.38 & $<0.01$ & $\mathrm{c}^{\prime}=0.15, \mathrm{~b}=0.18$ \\
\hline $1^{\text {st }}$ & the regression of $\mathrm{AEE}_{\mathrm{WD}}$ on GMC & 0.39 & $<0.01$ & $\mathrm{c}=0.20$ \\
\hline $2^{\text {nd }}$ & the regression of $\mathrm{T}_{\mathrm{NST}}$ on GMC & 0.27 & $<0.05$ & $\mathrm{a}=0.11$ \\
\hline $4^{\text {th }}$ & the regression of $\mathrm{AEE}_{\mathrm{WD}}$ on $\mathrm{T}_{\mathrm{NST}}$ and GMC & 0.41 & $<0.01$ & $\mathrm{c}^{\prime}=0.18, \mathrm{~b}=0.14$ \\
\hline $1^{\text {st }}$ & the regression of $\mathrm{PA}_{\vee}$ on $\mathrm{GMC}$ & 0.35 & $<0.05$ & $\mathrm{c}=0.17$ \\
\hline $2^{\text {nd }}$ & the regression of $\mathrm{T}_{\mathrm{NST}}$ on $\mathrm{GMC}$ & 0.27 & $<0.05$ & $\mathrm{a}=0.11$ \\
\hline $4^{\text {th }}$ & the regression of $\mathrm{PA}_{\checkmark}$ on $\mathrm{T}_{\mathrm{NST}}$ and GMC & 0.45 & $<0.01$ & $\mathrm{c}^{\prime}=0.13, \mathrm{~b}=0.35$ \\
\hline
\end{tabular}

Legend: $r$ - correlation coefficient, $p$ - significance level, $\mathrm{AEE}_{\mathrm{W}}$ - active energy expenditure during consecutive 7 days $\left(\mathrm{kcal}^{\circ} \times \mathrm{kg}^{-1} \times \mathrm{day}^{-1}\right)$, $\mathrm{AEE}_{\mathrm{WD}}$ - active energy expenditure for 5 weekdays $\left(\mathrm{kcal}^{\circ} \mathrm{kg}^{-1} \times\right.$ day $\left.^{-1}\right), \mathrm{PA}_{\mathrm{v}}-$ vigorous intensity physical activity $\left(\right.$ min. $\times$ day $\left.{ }^{-1}\right)$, GMC- gross motor coordination (standard score), $\mathrm{T}_{\mathrm{NST}}$ - total time in the Numeric square test (decile)

$8,000-11,500$ steps a day are considered to be healthy-sufficient amount for older school-age boys and 7,000-10,500 steps a day for older school-age girls (Sigmund, Frömel, \& Neuls, 2005). In our study, in comparison with these recommendations, we found in the $\mathrm{MD}^{+}$boys and the $\mathrm{MD}^{+}$girls number of steps a day falling into the lower borderline of recommended values of daily steps (TABLE 3 ). In comparison to these $\mathrm{MD}^{+}$ children, the $\mathrm{MD}^{-}$boys and $\mathrm{MD}^{-}$girls were more active when their average daily number of steps achieved the upper borderline of the recommended values. Based on the recommendation of 60 minutes of daily moderate to vigorous intensity PA (WHO, 2011), the groups of children in this study, regardless of gender and the level of their motor coordination skills, only reached the lower borderline of this recommendation.

The $\mathrm{MD}^{+}$boys performed significantly lower daily number of steps during the all week and also specially on weekdays. These findings are similar to the results of studies by Silman et al. (2011), according to which children with suspected DCD had, in comparison with children without DCD, lower amount of PA in both the weekdays and the weekends. Also studies of Baerga et al. (2011) and Castelli and Valley (2007) revealed a significantly lower amount of weekly PA indicated by the number of steps in the children, and particularly in boys with a low level of motor skills, compared to those with a normal level of motor skills.

In this study, the lower PA of the $\mathrm{MD}^{+}$boys than $\mathrm{PA}$ in the $\mathrm{MD}^{-}$boys was not reflected in a lower value of energy expenditure, although these $\mathrm{MD}^{+}$boys spent significantly less time with very high intensity PA (> 9 METs). However, the time proportion of very high intensity PA represented such a small proportion of children's daily PA, to have any possible influence on the differences in total energy expenditure between $\mathrm{MD}^{+}$boys and $\mathrm{MD}^{-}$boys. Similarly as in this study, the study of Baerg et al. (2011) did not find any significant difference in energy expenditure between children with DCD and the control group of children without DCD.

The $\mathrm{MD}^{+}$girls differed significantly from the $\mathrm{MD}^{-}$ girls in the lesser number of the PA variables than in the case of comparison of the PA variables between the $\mathrm{MD}^{+}$boys and $\mathrm{MD}^{-}$boys. The $\mathrm{MD}^{-}$girls spent significantly less time in vigorous PA (6-9 METs) than the $\mathrm{MD}^{-}$girls. In the study by Baerg et al. (2011) there were not found significant differences in the number of steps performed between the groups of girls with different levels of motor skills, on the other hand Cantell et al. (2008) found in girls with motor difficulties significantly lower daily vigorous PA during a week.

Only a few studies dealt with the problem of PA in children with DCD. The trend of lower participation of the $\mathrm{MD}^{+}$children in PA found in this study corresponds with the results of other studies (Silman et al., 2011; Baerg et al., 2011; Castelli \& Valley, 2007; Cantell, Crawford, \& Doyle-Barker, 2008). Although the differences in values of many PA indicators did not show as significant between the groups of children with the considerably different level of motor competency, the trend of the lower level of PA in $\mathrm{MD}^{+}$children was evident as compared to $\mathrm{MD}^{-}$children.

The limitations in the results of this study could be associated with the problem in validity of assessment of energy expenditure using the GT1M accelerometers. This type of accelerometer is uniaxial and thus detects the acceleration of the center of gravity in the vertical plane only. Another limit of this study was a small number of boys and girls in the particular groups. 
The total performance (TP) in the $\mathrm{d} 2$ attention test achieved by both the $\mathrm{MD}^{+}$and $\mathrm{MD}^{-}$children of both genders was slightly above-average, without no significant differences between the $\mathrm{MD}^{+}$and $\mathrm{MD}^{-}$subjects. These findings suggested that the attention effort related to its accuracy was similar among children regardless of the level of their motor development.

In the context of the above mentioned values of TP, it was an interesting fact that the concentration performance $(\mathrm{CP})$ in the $\mathrm{d} 2$ test in the $\mathrm{MD}^{+}$boys was very low corresponding to the 18.4 percentile. On the other hand, the $\mathrm{MD}^{-}$boys showed slightly above-average concentration of attention. According to Brickenkamp and Zillmer (2000) the CP variable reflects the qualitative aspects of visual attention and can be considered as an indirect indicator of the ability of visual differentiation of a subject. Based on the concept of the CP variable, the very low values of the $\mathrm{CP}$ in the $\mathrm{MD}^{+}$boys suggested a higher number of the errors of confusion of visual signs accompanied also with a higher number of the errors of omission. Then, these findings suggested that the $\mathrm{MD}^{+}$boys showed relatively excessive effort but simultaneously a lack of control. The low level of concentration of attention in the $\mathrm{MD}^{+}$boys indicated in the d2 test was confirmed by their below-average performance in the visual search task in the numerical square test of attention.

The study showed that the lower level of gross visuomotor coordination of children manifested in the aiming and catching tasks may be to some extent associated with a lower level of the concentration of attention. Concurrently, this study pointed to the possible existence of a mediation effect of concentration on the relationship between the level of the gross motor coordination and level of PA in older school-age children. The size of this mediation effect of concentration on participation of children on PA was found in the between 11-22\%. In other words, participation of a child in daily PA may be limited by his/her level of motor coordination mode underlying completing interceptive and targeting tasks, while this relationship may be also partly mediated by his/her concentration of attention as an individual psychological predisposition. The mediation effect of concentration was revealed repeatedly within three significant relationships between the component score for gross motor coordination on given three PA variables. Recently, Baerg et al. (2011) and other researchers critically have pointed out that the current research on DCD in children ignores a potential association of a motor difficulties and lower level of attention or attention disorder and a limiting effect of the both functional entities on the child's participation in PA.

\section{CONCLUSION}

From the assessed motor functions - fine and gross visuomotor coordination, and balance, only the gross motor coordination showed the significant relationship with PA. The explanation may be that the gross motor coordination and specially interceptive and targeting tasks are the part of movement and games activities which are typical for school-age children. The older children are more aware of their physical competence, and therefore the subjects with their perceived limits of motor skills can have a larger tendency to avoid those physical activities which could explain their lower competency (Hands \& Larkin, 2006; Cairney et al., 2005). Currently, the reduced ability of attention of a child may be one of the mediation factors within a number of the causes of the lower PA.

\section{ACKNOWLEDGEMENT}

The study was supported by the Czech Science Foundation in the frame of the projects No. P407/11/0946 and No. 406/09/1371.

\section{REFERENCES}

American Psychiatric Association (APA). (2000). Diagnostic and Statistical Manual of Mental Disorders (4th ed.). Washington, DC: American Psychiatric Association.

Baerg, S., Cairney, J., Hay, J., Rempel, L., Mahlberg, N., \& Faught, B. E. (2011). Evaluating physical activity using accelerometry in children at risk of developmental coordination disorder in the presence of attention deficit hyperactivity disorder. Research in Developmental Disabilities, 32(4), 1343-1350.

Barnhart, R. C., Davenport, M. J., Epps, S. B., \& Nordquist, V. M. (2003). Developmental coordination disorder. Physical Therapy, 83(8), 722-731.

Baron, R. M., \& Kenny, D. A. (1986). The moderatormediator variable distinction in socialpsychological research: Conceptual, strategic, and statistical considerations. Journal of Personality and Social Psychology, 51, 1173-1182.

Beauchet, O., Dubost, V., Gonthier, R., \& Kressig, R. W. (2005). Dual-task-related gait changes in transitionally frail older adults: The type of the walking-associated cognitive task matters. Gerontology, 51, 48-52.

Bouffard, M., Watkinson, E. J., Thompson, L. P., Causgrove Dunn, J. L., \& Romanow, S. K. E. (1996). A test of the activity deficit hypothesis with children with movement difficulties. Adapted Physical Activity Quarterly, 13, 61-73. 
Bowens, A., \& Smith, I. (1999). Childhood dyspraxia: Some issues for the NHS. Leeds: University of Leeds.

Brickenkamp, R., \& Zillmer, E. (2000). Test pozornosti $d 2$ (translated and adjusted by P. Balcar). Praha: Testcentrum.

Cairney, J., Hay, J. A., Faught, B. E., Wade, T. J., Corna, L., \& Flouris, A. (2005). Developmental coordination disorder, generalized self-efficacy toward physical activity and participation in organized and free play activities. Journal of Pediatrics, 147(4), 515-520.

Cairney, J., Hay, J. A., Wade, T. J., Faught, B. E., \& Flouris, A. (2006). DCD and aerobic fitness: Is it all in their heads or is measurement still the problem? Americal Journal of Human Biology, 18(1), 66-70.

Cairney, J., Hay, J. A., Faught, B. E., Flouris, A., \& Klentrou, P. (2007). Developmental coordination disorder and cardiorespiratory fitness in children. Pediatric Exercise Science, 19, 20-28.

Cantell, M., Crawford, S. G., \& Doyle-Barker, P. K. (2008). Physical fitness and health indices in children, adolescents and adults with high or low motor competence. Human Movement Science, 27(2), 344-362.

Castelli, D. M., \& Valley, J. A. (2007). Chapter 3: The relationship of physical fitness and motor competence to physical activity. Journal of Teaching in Physical Education, 26, 358-374.

Cermak, S. A., \& Larkin, D. (2002). Developmental coordination disorder. Albany, NY: Delmar.

Chambers, M., \& Sugden, D. (2006). Early years movement skills: Description, diagnosis and intervention. London: Whurr Publisher.

Chen, Y., Tseng, M., Hu, F., \& Cermak, S. A. (2009). Psychosocial adjustment and attention in children with developmental coordination disorder using different motor tests. Research in Developmental Disabilities, 30, 1367-1377.

Cohen, J. (1988). Statistical power analysis for the behaviour science (2nd ed.). New York, NY: Lawrence Erlbaum Associated.

Dewey, D., Kaplan, B. J., Crawford, S. G., \& Wilson, B. N. (2002). Developmental coordination disorder: Associated problems in attention, learning, and psychosocial adjustment. Human Movement Science, 21(5-6), 905-918.

Dwyer, C., \& Mckenzie, B. E. (1994). Impairment of visual memory in children who are clumsy. Adapted Physical Activity Quarterly, 11(2), 179-189.

Faught, B. E., Hay, J. A., Cairney, J., \& Flouris, A. (2005). Increased risk for coronary vascular disease in children with developmental coordination disorder. Journal of Adolescent Health, 37(5), 376-380.

Freedson, P. S., Melanson, E., \& Sirard, J. (1988). Calibration of the computer science and applications, inc. accelerometer. Medicine \& Science in Sports \& Exercise, 30(5), 777-781.

Frömel, K., Novosad, J., \& Svozil, Z. (1999). Pohybová aktivita a sportovní zájmy mládeže. Olomouc: Univerzita Palackého.

Frömel, K., Pelclová, J., Skalik, K., Nováková Lokvencová, P., \& Mitáš, J. (2012). The association between participation in organised physical activity and a level of physical activity and inactivity in adolescent girls. Acta Universitatis Palackianae Olomucensis. Gymnica,42(1), 7-16.

Hands, B., \& Larkin, D. (2006). Physical fitness differences in childreen with and without motor learning difficulties. European Journal of Special Needs Education, 21(4), 447-456.

Henderson, S. E., Sugden, D. A., \& Barnett, A. L. (2007). Movement Assessment Battery for Children-2. London: Harcourt Assessment.

Jirásek, J. (1975). Test pozornosti Číselný Čtverec. Bratislava: Psychodiagnostické a didaktické testy n. p.

Kim, H. M., Yang, Y. J., Yun, Y. S., Lee, E. S., Lee, D. E., \& Jeon, H. J. (2008). The accuracy of the accelerometers (Actical and Actigraph) among Korean People. Journal of Korean Academy of Family Medicine, 29(9), 668-674.

Licari, M., \& Larkin, D. (2008). Increased associated movements: Influence of attention deficits and movement difficulties. Human Movement Science, 27, 310-324.

Martin, C. N., Piek, J. P., \& Hay, D. (2006). DCD and ADHD: A genetic study of thein shared aetiology. Human Movement Science, 25(1), 110-124.

Maylor, E. (2001). Effects of spatial and nonspatial cognitive activity on postural stability. British Journal of Psychology, 9, 319-338.

Pereira, H. S., Landgren, M., Gillberg, C., \& Forssberg, H. (2001). Parametric control of fingertip forces during precision grip lifts in children with DCD and DAMP. Neuropsychologia, 39, 478-488.

Pitcher, T. M., Piek, J. P., \& Hay, D. A. (2003). Fine and gross motor ability in males with ADHD. Developmental Medicine and Child Neurology, 45, 525-535.

Psotta, R., Vodička, P., Heller, J., \& Soukup, V. (2007). Validita a reliabilita akcelerometru actigraph, model GT1M: pilotní studie. Česká kinantropologie, 11(2), 35-44.

Rankin, J. K., Woollacott, M. J., Shumway-Cook, A., \& Brown, L. A. (2000). Cognitive influence on postural stability: A neuromuscular analysis in young and older adults. The Journal of Gerontology, 55A(3), 112-119.

Rivilis, I., Hay, J., Cairney, J., Klentrou, P., Liu, J., \& Faught, B. E. (2011). Physical activity and fitness in children with developmental coordination disorder: 
A systematic review. Research in Developmental Disabilities, 32(3), 894-910.

Shum, S. B. M., \& Pang, M. Y. C. (2009). Children with attention deficit hyperactivity disorder have impaired balance function: involvement of somatosensory, visual, and vestibular systems. The Journal of Pediatric, 155(2), 245-249.

Schott, N., Alof, V., Hultsch, D., \& Meermann, D. (2007). Physical fitness in children with developmental coordination disorder. Research Quarterly for Exercise and Sport, 78(5), 438-450.

Sigmund, E., Frömel, K., \& Neuls, F. (2005). Pohybová aktivita dětí a mládeže: ukazatele $\mathrm{k}$ hodnocení $\mathrm{z}$ hlediska podpory zdraví. Acta Universitas Palackianae Olomoucensis. Gymnica, 35(2), 59-68.

Silman, A., Cairney, J., Hay, J., Klentrou, P., \& Faught, B. E. (2011). Role of physical activity and perceived adequacy on peak aerobic power in children with developmental coordination disorder. Human Movement Science, 30(3), 672-681.

Skinner, R. A., \& Piek, J. P. (2001). Psychosocial implications of poor motor coordination in children and adolescents. Human Movement Science, 20(1-2), 73-94.

Sundermier, L., Woollacott, M., Roncesvalles, N., \& Jensen, J. (2001). The development of balance control in children: Comparisons of EMG and kinetic variables and chronological and developmental groupings. Experimental Brain Research, 136(3), 340-350.

Troped, P. J., Wiecha, J. L., Fragala, M. S., Matthews, C. E., Finkelstein, D. M., Kim, J., \& Peterson, K. (2007). Reliability and validity of YRBS physical activity items among middle school students. Medicine \& Science in Sports \& Exercise, 39(3), 416-425.

Volman, J. M., \& Geuze, R. H. (1998). Relative phase stability of bimanul and visiomanual rhythmic coordination problems in children with a developmental coordination disorder. Human Movement Science, 17(4-5), 541-572.

Wann, J. P., Williams, M. M., \& Rushton, K. (1998). Postural control and co-ordination disorders: The swinging room revisited. Human Movement Science, 17(4-5), 491-513.

Welk, G. J., Schaben, J. A., \& Morrow, J. R. (2004). Reliability of accelerometry-based activity monitors: A generalizability study. Medicine \& Science in Sports \& Exercise, 36(9), 1637-1645.

Wilms Floet, M. A., \& Maldonado-Durán, M. J. (2006). Motor skills disorder [on-line]. Retrieved 18. 7. 2010 from the World Wide Web: http://emedicine.medscape.com/article/915251-overview

Woollacott, M., \& Shumway-Cook, A. (2002). Attention and the control of posture and gait: A review of an emerging area of research. Gait and Posture, $16,1-14$.

\section{VZTAH MEZI ÚROVNÍ MOTORICKÉ KOORDINA- CE, KONCENTRACÍ POZORNOSTI A POHYBO- VOU AKTIVITOU U DĚTÍ: MEDIAČNÍ MODEL}

(Souhrn anglického textu)

VÝCHODISKA: Současná zjišsění poukazují na fakt, že pohybová aktivita dětí s vývojovými poruchami může být limitována sníženou úrovní motorické koordinace. Motorické obtíže jsou u dětí často spojeny s př́itomností poruchy koncentrace pozornosti.

CÍLE: Cílem studie bylo zjistit úroveň pohybové aktivity (PA) u dětí staršího školního věku s motorickými obtížemi $(\mathrm{MD}) \mathrm{v}$ porovnání s dětmi bez $\mathrm{MD}$ a následně odhalit možný mediační efekt koncentrace pozornosti mezi úrovní pohybových dovedností a pohybovou aktivitou dětí.

METODIKA: Účastníci byli rozděleni do dvou skupin: 15 dětí s MD $(13,7 \pm 1,6$ let $)$ a 27 dětí bez MD $(13,3 \pm 1,4$ let$)$. Pohybové funkce byly hodnoceny pomocí testové baterie MABC-2, týdenní PA s využitím akcelerometrů Actigraph a koncentrace pozornosti byla hodnocena s využitím pozornostních testů d2 a číselný čtverec. K hodnocení mediačního efektu koncentrace pozornosti jsme použili mediační analýzu podle Barona a Kennyho (1968).

VÝSLEDKY: Ve většině ukazatelů PA dosáhly děti s MD nižší hodnoty v porovnání s dětmi bez MD. Signifikantní rozdíly byly zjištěny v počtu kroků za týden, v průběhu pracovních dnů $(d=0,50$, resp. 0,64$)$ a v PA velmi vysoké intensity $(d=2,00)$ mezi chlapci s a bez MD. U dívek s MD jsme zaznamenali signifikantně nižší čas strávený PA vysoké intensity $(d=0,86)$. Výsledky studie podporují hypotézu o vývojovém deficitu motoriky jako rizikovém faktoru PA u dětí staršího školního věku. Signifikantní mediační efekt koncentrace pozornosti ve vztahu mezi úrovní pohybových dovedností a PA byl zjištěn ve třech případech - ve vztahu mezi hrubou motorikou na straně jedné, a energetickým výdejem za týden, v pracovních dnech a PA vysoké intensity na straně druhé. Velikost mediačního efektu koncentrace pozornosti se pohybovala v rozmezí 12-22\%.

ZÁVĚRY: Výsledky studie naznačují, že účast dětí v PA může být silně ovlivněna úrovní jejich interceptivních a míricích dovedností, ve kterých hraje klíčovou roli vizuomotorická koordinace. Omezená schopnost koncentrace pozornosti u dětí pak může být jedním $\mathrm{z}$ mediačních faktorů, které snižují úroveň PA.

Klíčová slova: vizuomotorická koordinace, rovnováha, energetický výdej, kroky, koncentrace pozornosti, mediace. 
Mgr. Jakub Kokštejn, Ph.D.

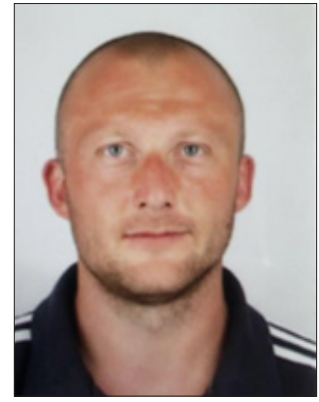

Charles University

Faculty of Physical Education and Sport

José Martího 31

16000 Praha 6 - Veleslavín

Czech Republic

\section{Education and previous work experience}

2007-2012 - Doctoral study program at Charles University in Prague, Faculty of Physical Education and Sport.

2001-2006 - Master's study program at Charles University in Prague, Faculty of Physical Education and Sport. Scientific orientation

Explorational activity in the field of kinanthropology with an orientation to movement difficulties in children, physical activity and inactivity in different population groups.

\section{First-line publications}

Kokštejn, J., Jahodová, G., Frýbort, P., \& Vodička, P. (2009). Motor difficulties as the factor of overweight and obesity of older school-age children. Acta Facultatis Educationis Physicae Universitatis Comenianae, 49(2), 49-58.

Psotta, R., \& Kokštejn, J. (2009). Body mass index in older school age children with and without motor difficulties. Ovidius University Annals, Series of Physical Education and Sport (Science, Movement and Health), 9(2), 170-174.

Kokštejn, J., Psotta, R., Frömel, K., Frýbort, P., Jahodová, G., \& Cuberek, R. (2011). Pohybová aktivita dětí s vývojovým deficitem motoriky. Česká kinantropologie, 15(3), 76-88.

Frýbort, P., \& Kokštejn, J. (2013). Vliv pohybového zatížení na vizuálně-motorickou odpověd' u elitních juniorských fotbalistů. Česká kinantropologie, 17(2), 29-37. 